\title{
An Analysis of Competency for Hydrogen Energy and Full Cell in Taiwan
}

\author{
W. J. Hsiao
}

\begin{abstract}
Hydrogen energy and fuel cell industry just developed a few years ago in Taiwan, experience and professional high-tech worker are not enough to satisfy these fast expand request. It seems a big gap between human resource demand and supply. To develop and train these high-tech workers, this research is trying to find out the work competence in Hydrogen Energy and Fuel Cell worker. Appling quantitative approach to explore the depth and broadness of the knowledge of core competence, two frameworks are proposed: building the context system of core competence concept, and constructing the learning model for the core competence. The paper describes the specific and general skills and how higher-education curricula align with workforce needs. In conclusion, appropriate suggestions of training system are proposed to push ahead the future development of Taiwan's Hydrogen Energy and Fuel Cell industry.
\end{abstract}

Index Terms-Hydrogen energy and full cell, new energy, competency.

\section{INTRODUCTION}

The gaseous waste discharged by petrochemical energy is the main reason for the Greenhouse effects that cause climate changes around the world. The present average temperature of the earth is higher than that of 20 years ago. Global climate change and energy crisis urge all countries to think about the next new energy [1]. Hydrogen energy and fuel cell is cleaner, more efficient, and versatile renewable energy [2], [3]. Many countries take hydrogen energy and fuel cell as the next new energy. Solar power, LED illumination, wind power generation, bio-fuels, hydrogen energy and fuel cells, energy ICT and electric vehicles were choose to Green Energy Development Plane in Taiwan. However, hydrogen energy and fuel cell industry just develop a few years ago in Taiwan, compared with solar power and LED illumination, hydrogen energy and fuel cell is infant industry in Taiwan [4]. Experience and professional high-tech workers are not enough to satisfy the fast expand request in hydrogen energy and fuel cell industry. It's time to have renewable energy's workforce development and education activities support the further development and enhancement of these critical workforce skills.

This research is trying to find out the work competency in hydrogen energy and fuel cell industry. Competency model is considered and efficiently in particle and in academic analysis [5]. Confirming key competence items for hydrogen

Manuscript received November 30, 2012; revised January 22, 2013.

This work was supported in part by the Taiwan National Science Council (NSC101-3113-S-260-001).

W. A. Hsiao is with the Graduate Institute of Adult and Continuing Education, National Chi Nan University (NCNU), Taiwan (e-mail: wjhsiao@ncnu.edu.tw). energy and fuel cell worker will be helpful to their development and training programs. Finally, we will propose core competency for hydrogen energy and fell cell.

\section{RESEARCH OBJECTS}

While the world's economy is slowly recovering and improving, green collar economy is booming [6]. It's critical period of business transformation in Taiwan. Green energy may be the next emerging industry [7]. Having the advantage of high efficiency, low pollution, and widely using, hydrogen and full cells have become one of the main green energy in Taiwan [8]. There are both threats and opportunities in labor market responses to climate change policies. Some people will switch careers to green industry, and they will be active to learn more about the renewable energy. The highly nature of the energy generation industry poses particular challenges for planning how existing workers can be re-trained or re-distributed effectively into newer jobs and industries. Therefore, green-job training programs or certificate program are needed. The changes to the energy labor market will largely be dependent on the kinds of alternate energy solutions that Taiwan adopts. The aim was to gain better insight into how the greening economy is affecting the job market. The new prominence of environmental considerations is already having an impact on the job market. Workers from all walks of life need to expand their skill set so that they can help safeguard the environment. Here are some questions addressed by this paper:

1) Which specific and general skills are new and emerging in hydrogen energy and fuel cell industry?

2) Which occupations are needed in hydrogen energy and fuel cell industry?

3) How can education and training systems be developed to respond quickly to the industrial needs?

4) How can educational and training standards be brought closer to occupational standards and employer priorities in green jobs?

5) How higher-education curricula align with workforce needs?

\section{Methodology}

The subsequent surge in the number of hydrogen and fuel cell companies, have created a big imbalance between supply and demand for green workers. Experience and professional workers are not enough to satisfy these fast expand. The purpose of this research is exploring the competency for hydrogen energy and full cell, and proposal some training 
program for new energy worker. Using multiple-case study [9], document analysis, and depth interviews [10], the competency framework and training program will be proposed. Study procedures as Fig. 1:

TABLE I: COMPETENCE FOR HYDROGEN AND FuEL CELL INDUSTRY CHAIN

\begin{tabular}{|c|c|c|c|}
\hline & $\begin{array}{l}\text { Upstream: } \\
\text { Fuel Supply, } \\
\text { Material } \\
\text { Components }\end{array}$ & $\begin{array}{l}\text { Midstream: } \\
\text { Fuel Cell Manufacturing and Testing }\end{array}$ & $\begin{array}{l}\text { Downstream: } \\
\text { System Application and Design }\end{array}$ \\
\hline Subjects & $\begin{array}{l}\text { materials, } \\
\text { chemistry, } \\
\text { chemical, } \\
\text { electrochemistry, } \\
\text { machinery, high } \\
\text { polymer, thermal } \\
\text { conduction }\end{array}$ & $\begin{array}{l}\text { materials, chemistry, electrochemistry, } \\
\text { machinery, high polymer, heat recovery, } \\
\text { thermal conduction }\end{array}$ & $\begin{array}{l}\text { electricity, software, electrical, machinery, system control, } \\
\text { marketing, business }\end{array}$ \\
\hline $\begin{array}{l}\text { Core } \\
\text { competence }\end{array}$ & $\begin{array}{l}\text { good teamwork } \\
\text { spirit, } \\
\text { communication } \\
\text { capability, } \\
\text { independent } \\
\text { thinking, sharing, } \\
\text { frustration } \\
\text { tolerance, positive } \\
\text { attitude, } \\
\text { responsibility, and } \\
\text { absorption, } \\
\text { enthusiasm, } \\
\text { creativity }\end{array}$ & $\begin{array}{l}\text { good teamwork spirit, communication } \\
\text { capability, independent thinking, sharing, } \\
\text { frustration tolerance, positive attitude, } \\
\text { responsibility, and absorption, enthusiasm, } \\
\text { personality }\end{array}$ & $\begin{array}{l}\text { good teamwork spirit, communication capability, independent } \\
\text { thinking, sharing, frustration tolerance, positive attitude, } \\
\text { responsibility, and absorption, enthusiasm, creativity }\end{array}$ \\
\hline $\begin{array}{l}\text { Professional } \\
\text { competence }\end{array}$ & $\begin{array}{l}\text { knowledge of the } \\
\text { basis of } \\
\text { polytechnic, } \\
\text { material cost } \\
\text { control, } \\
\text { development of } \\
\text { new materials, } \\
\text { chemistry, } \\
\text { chemical, } \\
\text { electrochemical, } \\
\text { product } \\
\text { market-oriented, } \\
\text { battery design, } \\
\text { heat conduction } \\
\text { experience }\end{array}$ & $\begin{array}{l}\text { knowledge of the basis of polytechnic, } \\
\text { chemical, electrochemical, machinery, } \\
\text { product market-oriented, settings the heat } \\
\text { flow catheter }\end{array}$ & $\begin{array}{l}\text { knowledge of the basis of polytechnic, electrical, mechanical } \\
\text { structure, electric power administration, software design, } \\
\text { system control }\end{array}$ \\
\hline
\end{tabular}

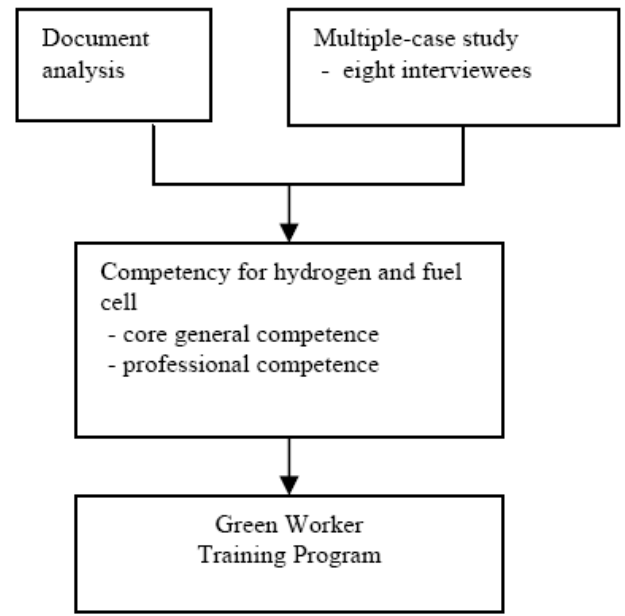

Fig. 1. Study procedures

Via reviewing relevant literatures, we will clarify and define the contents and conceptual benchmarks of hydrogen and full cells. To validate the instrument development framework by interviewing chief managers various from hydrogen and full cells industry chain. Eight companies on behalf upstream, midstream, and downstream companies, nine chief managers were interviewed to gather information about specific and general skills are new and emerging in hydrogen and fuel cell industry. Valid conceptual competence in hydrogen and fuel cell industry will proposed that comprehensively define hydrogen and fuel cell related content knowledge, attitudes, and personality.

\section{CONCLUSION}

The value of knowledge assets play even more important role as the competition is getting vigorous in nowadays [11]. Therefore, the vehicle of knowledge, human resource, of organization is becoming the major focus [12]. Especially, hydrogen and fuel cell is still infant industry in Taiwan, it is needed to conduct the content of skilled workforce. The present study addresses the gap in literature of competence in hydrogen and fuel cell. How to employ the core competency model to acquire the winning edge in the industry is the utmost unanswered question in the mind of the academician and the field manager. The present study addresses this gap in the literature, and try to conduct the knowledge, skills, and abilities that successful green worker demonstrate on the job.

This research intends to clarify the content and context of the concept of core competence as the starting point. After that, the research tries to develop a technique with comprehensive theory base and applicable tools to help field 
people identify the hydrogen and fuel cell core competences. Based on these understandings, this research tries to construct the learning model for each identified core competence in that of industry survey.

The research applies quantitative approach to explore the depth and broadness of the knowledge of core competence. Document analysis and depth interviews are used to support our arguments. The competency framework and the training program may be promoted to and adopted in the future. According to the results, two frameworks are proposed: building the context system of core competence concept, and constructing the learning model for the core competence.

\section{A. The Context of Core Competence in Hydrogen and Fuel Cell}

According to the results of this research, some specific and general skills are emerging in hydrogen energy and fuel cell industry. We identity eight core general competence: good teamwork spirit, communication capability, independent thinking, sharing, frustration tolerance, positive attitude, responsibility, and absorption. Workers with some of that core general competence, hat successful green worker demonstrate on the job. But, competence for hydrogen and fuel cell industry chain is diverse. What it need for upstream is different from downstream. Further description for hydrogen and full cell industry chain was shown in Table I.

\section{B. The Learning Model for the Core Competence}

The workforce could be divided into two groups: school student and employee. They may have different learning programs. Here, we propose learning programs on the translation between competence standards and curriculum development from the aspect of industrial-driven. The training $r$ programs are mainly divided into internal training, external training, and tertiary education, and we proposed that in Table II. The result can provide the basis of recruiting and training.

\begin{tabular}{lll}
\multicolumn{3}{c}{ TABLE II: CHANNEL OF TRAINING } \\
\hline \hline Curriculum development & \multicolumn{1}{c}{ Internal training } & External training \\
\hline self-directed learning, & R \& D team, & advanced studies, \\
case study, team training, & on-job-training, & public courses, \\
monographic study, & apprenticeship, & off-job-training, \\
industry-university & industry-university & conference, \\
collaboration projects & collaboration projects & discussion forum \\
\hline \hline
\end{tabular}

\begin{tabular}{|c|c|c|c|c|}
\hline \multicolumn{5}{|c|}{ APPENDIX } \\
\hline & Needs & School education & Internal training & External training \\
\hline \multirow{7}{*}{ 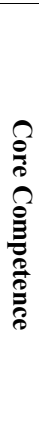 } & Absorptive capacity & $\begin{array}{l}\text { Participate in thematic activities, } \\
\text { Self-directed learning }\end{array}$ & & $\begin{array}{l}\text { Advanced studies, } \\
\text { Discussion forum }\end{array}$ \\
\hline & Positive attitude & $\begin{array}{l}\text { Participate in thematic activities, } \\
\text { Simulation training }\end{array}$ & & \\
\hline & Responsibility, Enthusiasm & $\begin{array}{l}\text { Participate in thematic activities, } \\
\text { Simulation training, Case studies }\end{array}$ & & \\
\hline & Frustration tolerance & $\begin{array}{l}\text { Participate in thematic activities, Simulation } \\
\text { training }\end{array}$ & & \\
\hline & Independent thinking & $\begin{array}{l}\text { Participate in thematic activities, } \\
\text { Case studies }\end{array}$ & & \\
\hline & $\begin{array}{l}\text { Teamwork spirit, } \\
\text { communication }\end{array}$ & $\begin{array}{l}\text { Participate in thematic activities, } \\
\text { Team training }\end{array}$ & $\mathrm{R} \& \mathrm{D}$ team & \\
\hline & Creativity & $\begin{array}{l}\text { Participate in thematic activities, } \\
\text { Self-directed learning }\end{array}$ & $\mathrm{R} \& \mathrm{D}$ team & \\
\hline \multirow{11}{*}{ 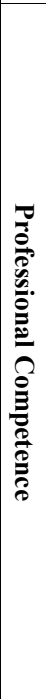 } & $\begin{array}{l}\text { Knowledge of the basis of } \\
\text { Polytechnic }\end{array}$ & Academic credit learning & on-job-training & $\begin{array}{l}\text { Advanced studies, } \\
\text { Courses of public sector }\end{array}$ \\
\hline & Material cost control & Academic credit learning & $\begin{array}{l}\text { apprenticeship training, } \mathrm{R} \& \mathrm{D} \\
\text { team }\end{array}$ & $\begin{array}{l}\text { Discussion forum, } \\
\text { Courses of public sector }\end{array}$ \\
\hline & Development of new materials & Participate in thematic activities & $\begin{array}{l}\text { Produces study the cooperation, } \mathrm{R} \\
\text { \& D team }\end{array}$ & $\begin{array}{l}\text { Advanced studies, } \\
\text { Courses of public sector }\end{array}$ \\
\hline & Electric power administration & $\begin{array}{l}\text { Participate in thematic activities, Simulation } \\
\text { training }\end{array}$ & $\begin{array}{l}\text { apprenticeship training, Behaviors } \\
\text { emulate }\end{array}$ & Courses of public sector \\
\hline & Battery design & $\begin{array}{l}\text { Simulation training, industry-university } \\
\text { collaboration projects }\end{array}$ & $\begin{array}{l}\text { apprenticeship training, } \mathrm{R} \& \mathrm{D} \\
\text { team }\end{array}$ & Courses of public sector \\
\hline & Heat conduction experience & $\begin{array}{l}\text { Simulation training, industry-university } \\
\text { collaboration projects }\end{array}$ & $\begin{array}{l}\text { apprenticeship training, } \mathrm{R} \& \mathrm{D} \\
\text { team }\end{array}$ & \\
\hline & Settings the heat flow catheter & $\begin{array}{l}\text { Simulation training, industry-university } \\
\text { collaboration projects }\end{array}$ & $\begin{array}{l}\text { apprenticeship training, Team } \\
\text { Training }\end{array}$ & \\
\hline & Software Design & $\begin{array}{l}\text { Simulation training, industry-university } \\
\text { collaboration projects }\end{array}$ & Produces study the cooperation & $\begin{array}{l}\text { Advanced studies, } \\
\text { Courses of public sector }\end{array}$ \\
\hline & System Control & $\begin{array}{l}\text { Participate in thematic activities, } \\
\text { industry-university collaboration projects }\end{array}$ & $\begin{array}{l}\text { apprenticeship training, Produces } \\
\text { study the cooperation }\end{array}$ & \\
\hline & Electric power administration & $\begin{array}{l}\text { Academic credit learning, Simulation } \\
\text { training }\end{array}$ & apprenticeship training & Courses of public sector \\
\hline & Product market-oriented & $\begin{array}{l}\text { Discussion forum, industry-university } \\
\text { collaboration projects }\end{array}$ & $\begin{array}{l}\text { apprenticeship training, R \& D } \\
\text { team }\end{array}$ & Discussion forum \\
\hline
\end{tabular}

As the era of low-carbon economy has come, the energy technology development is not only related with the future of the wellbeing of humanity, but also directly affects the economic development in one's country. Taiwan lacks natural resources and the degree of dependence on energy imports is as high as $99.3 \%$. However, Taiwan has excellent $\mathrm{R} \& \mathrm{D}$ and manufacturing capacity. If we deepen the development of new energy technology, it will become the next engine to lead Taiwan industry. The current issue is the workers need to expand their skill that can help them switch to new industry. This study aims to explore the hydrogen energy and fuel cell industry, and confirm core competence for hydrogen energy and fuel cell industry. Through the core competence assessment, we describe and plan the industrial learning paths and make recommendations for the training system for enterprises, schools and related organizations in 
training and selection of personnel.

\section{REFERENCES}

[1] F. Charles, "The real path to green energy: Hybrid nuclear-renewable power," Bulletin of the Atomic Scientists, vol. 65, no. 6, pp. 65-71, Nov. 2009.

[2] B. S. Sharma and A. J. Thakkar, "Correlation energy generating potentials for molecular hydrogen," Journal of Chemical Physics, vol. 83, no. 7, pp. 3577-84, Oct. 1985.

[3] D. Lee, "Toward the clean production of hydrogen: Competition among renewable energy sources and nuclear power," International Journal of Hydrogen Energy, vol. 37, no. 20, pp. 15726-15735, Oct. 2012.

[4] W. Huang, "Taiwan deal for harvest energy hydrogen unit," Fuel Cells Bulletin, vol. 4, pp. 8-8, Apr. 2007.

[5] L. M. Spencer and S. M. Spencer, Competence at work: Model for superior performance, New York: John Wiley \& Sons, Inc., 1993.

[6] P. Alicia and S. Frank, "Green-collar jobs: Employment impacts of climate change policies," Journal of Australian Political Economy, vol. 62, pp. 120-138, Dec. 2008.

[7] B. Lin, "AUO takes major leap into green energy business," Worldwide Energy, vol. 20, no. 2, pp. 5-7, Feb. 2009.
[8] A. Nnorom, "Fuel cells types and characterization," Nature \& Science, vol. 9, no. 11, pp. 116-124, Nov. 2011.

[9] R. K. Yin, Applications of case study research, (2nd Ed.). 2Thousand Oaks, CA: Sage 2003.

[10] M. Q. Patton, Qualitative Evaluation and Research Methods, Newbury Park: Sage publications, 1990.

[11] J. R. Downing, "Linking communication competence with call center agents' sales effectiveness," Journal of Business Communication, vol. 48, no. 4, pp. 409-425, 2011.

[12] S. Rettinger, "Construction and display of competence and (Professional) identity in coaching interactions," Journal of Business Communication, vol. 48, no. 4, pp. 426-445, 2011.

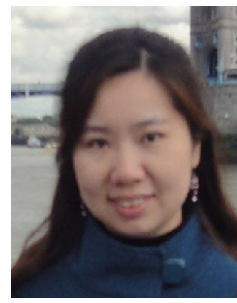

Wan-Jung Hsiao was born in May 1979. She is a Taiwan scholar and she was educated at the Graduate Institute of Human Resource Management in National Central University, and served as associate professor at the National Chi Nan University. She studied human resource development and training, organizational behavior, and performance management. Her writings on this issue have appeared in several journal and conference 